\title{
The case for Pacific media reform to reflect island communities
}

KALAFI MOALA

Publisher, Lali Media Group

7 HE LARGEST number of Tongans outside of Tonga lives in the United States. It is estimated to be more than 70,000; most live in the San

1 Francisco Bay Area. On several occasions during two visits to the US by my wife and I during 2004, we met workers who operate the only daily Tongan language radio programmes in San Francisco. Our organisation supplies the daily news broadcast for their programmes. Our newspapers - in the Tongan and Samoan languages - also sell in the area.

The question of what are the fundamental roles of media came up in one of our discussions. One of the best comments I heard was that the media's fundamental role is to reflect as accurately and equitably as possible the society in which it operates and of which it is a part. I was quite surprised and impressed with the degree of media literacy these untrained community radio broadcasters had. They seemed to understand well their mission, even though they do this part-time.

Media should be likened to a mirror, if you like, reflecting what is going on, what people are doing that is making a difference, and the issues affecting their lives. As journalists, we write, speak, film and even paint the stories of what is going on in our societies. News stories, however, are never written or broadcast in a vacuum, for they are written or told within the framework of cultural, social and historical contexts.

In recent years there have been calls for better journalism education and training of Pacific Island journalists. I think we should be encouraged at the kinds of things that are being done in this regard. The fact that a regional media conference was held in Suva in December 2004, and that there is an organisation such as the Journalism Education Association (JEA), is testi- 
mony to the fact that this call for more and better training has not been in vain. Those of us who are in the frontlines of daily media practice can only express gratitude to those who are educators and trainers of journalists in our region. There are tremendous things being done in universities in Australia and New Zealand, Papua New Guinea and Hawaii - and at the region's University of the South Pacificin Fiji - to make the best journalism training available to the young people of our region.

However, just as there have been calls for constitutional and political reforms in most of our Pacific Island states, I believe a major reform is needed in the media systems and operations of our region. To train journalists and media practitioners and then send them in to work in the current media systems of our region would be like sending in soldiers to a war zone without a mission.

Such needed reform in media would mean the masses of common people at least have some form of control of the media, rather than media being hijacked by island government policies allied with elitist and corporate financial interests. There are three main observations that have brought me to this conclusion:

1. Since most of the major media operations in the region have been government owned or controlled, there is an inevitable bias in the way news is being covered. Island journalists play servants sometimes to corrupt policies formulated without public participation - and in some cases these policies have been unconstitutionally and unlawfully formulated and executed.

2. Media business and commercial interests have usurped the traditional role of adequately informing people. They may be entertained, horrified, titillated, and stressed, but not informed.

3. Globalisation has impacted on media to such an extent that less is being done to make media appropriate to indigenous and local social-cultural contexts; rather local socio-cultural contexts are being 'progressively adapted' to fit the 'one shoe' of globalised media. This results in increasing ignorance of local cultural protocols, and the minimising of the importance of language and history education. We are inundated with massive information overload quite irrelevant to the majority of people, and we continue to be writing about the elite and for the elite. The mass of common people and their stories have largely been ignored. 


\section{Government-controlled media and government media policies}

In our region over the years there have been frequent spats and, in some cases, serious standoff situations between island governments and the news media. Whether in Papua New Guinea, Solomon Islands, Vanuatu, Fiji, Cook Islands, Niue, Kiribati, or Tonga, the quarrels have often been between particular island governments and the independent news media - media not controlled by government. In just about every case, by using propaganda through their own media, island governments have targeted dissenting media with accusations of 'unprofessionalism', 'unbalanced reporting' and even 'cultural insensitivity'.

In Tonga's case, it was serious enough that the government acted foolishly to change the constitution and pass media and newspaper laws to discriminately ban the media they dislike and issue licences to the ones that support them. This approach resulted in a major constitutional challenge where the Supreme Court of Tonga ordered the abolition of the media and newspaper legislations.

What has amazed me over the years is that in almost every case where there is a quarrel between an island government and the media, the governments of New Zealand and Australia - through their local diplomatic representatives offer to help solve the problem by funding training seminars and programmes for media. Note that it is always the media which get training. I cannot think of many cases in which island governments are offered training for their ministers on how to be transparent, on how not to oppress free expression, and in how to refrain from corrupt practice and behaviour.

Part of the problem, of course, is the imbedded notion among island governments that those who exercise authority know best what is good for society. They believe the public in general is 'dumb' and ignorant, and need not question government policies and practices because they are for the good of the public. This was well illustrated in a sworn testimony before the Supreme Court of Tonga. Chief Secretary to Government, and Chief Spokesperson, 'Eseta Fusitu'a, said: 'The public, they do not know what's wrong, (or) what's right. Government does.' 1

There is, I contend, a bizarre notion in many of our island states that what is good for government is good for the people. Therefore, it is claimed, it is the right of government to have media serve its interests, for in serving government interests, it serves the interests of the nation. It is imperative that 
media remain independent of government control and regulation, for in every island state there are already statutory laws that provide protection from abuse by media.

As long as media are controlled or manipulated in any way by government, the media would be minimised or scared off their role of being a watchdog of the powers that be. There is a Biblical story of an Israeli king, David, who became arrogant and corrupt in his dealings despite the fact that he had served his people well on his way to becoming king. He pursued another man's wife, made her pregnant then conspired with his top general to place the husband at the forefront of the battle so he would get killed. The king violated basic morality and human rights, and committed a crime that displeased God.

In this Israeli kingdom, there was an old journalist called Nathan. They called journalists in those days prophets. And so Nathan set up an interview with the king, and told a story about a rich man and a poor man. He said the rich man had everything, but the poor man only had a little lamb. Being from the islands, let us just call this lamb a 'piglet' - even though that would be anathema to Israelis.

So, Nathan wanted to ask the first question but he had to do it in the form of a story. He said the rich man had guests and instead of killing one of his own pigs, he commanded his gangsters to slaughter the poor man's piglet and roast it for his guests. This left the poor man with absolutely nothing.

Nathan the Journalist asked King David, 'What would you do?' Burning with anger, the king replied that the rich man deserved to die, for he had no pity on the poor man. Nathan, being the investigative journalist that he was, looked up from his note-taking, pointed his finger at the camera and said to the king: 'You are that man!'

Unafraid of what might happen to him, Nathan allowed the king to write his own story, and at the end, the king saw the error of his own ways and repented. ${ }^{2}$

This 'prophet role' of media, holding our rulers to account, and the powers that be to refrain from corruptive practice, must never be lost to a heavily compliant and entertaining media. Our industry has set its eyes on 'Profit Making' so much so that we neglect 'Making Prophets' in our training and education programmes, where critical thinking and philosophical analysis are no longer required; and where history, cultural anthropology, and sociol- 
ogy are replaced by required courses on business, commerce, and management technology.

\section{Commercial interest at the expense of public service}

Some years ago, when I was visiting Suva, I ran into a journalist friend whose first question to me concerning the new newspaper I had started was: 'Are you making any money?' That was a reasonable and good question. I had not thought of it since the newspaper was launched, if we were making money or not. We were happy to be selling lots of newspapers, not because of the money but because people were reading the newspaper. But whenever I had met someone from the media, they would always address me with this question: 'Are you making any money?'

Our newspaper team was so excited at the thought of producing a newspaper to inform the people of Tonga freely without restriction, we had not thought about the money side of things. And, of course, we needed money to be able to continue. We have always been challenged with commercial interests at the expense of public service. On more than a few occasions, wealthy advertisers have tried to influence our editorial policy.

Our experience is not unique. Throughout the Pacific, media have been subjected to the seduction of big corporate dollars and funding agencies. Education per se has been subjected to the lure of the moneymen.

Research, for example, is no longer conducted because there is a significant need to conduct an enquiry and search for 'truth'. Research is now redefined as what you do under the direction of the funding agencies.

When international media corporations come into the region, they are normally more interested in enriching their investors than serving the public of the region. Even our big brothers, New Zealand and Australia, through radio and television, and even print media, make their mark in what Robert W. McChesney and John Nichols (2002) call 'hyper commercialism and denigration of public service'. Speaking about media in America, they said:

As massive media corporations are better able to commercially saturate society, their ability or willingness to provide material with editorial and creative integrity declines. It is not that the individuals who run these firms are bad people, the problem is that the system of business in America is designed for profit making, not public interest, and thus we 
have a media system set up to enrich investors, not serve democracy. (McChesney \& Nichols, p. 52)

Media set up under this kind of system 'works to advance the interests of the wealthy few, rather than the many'. What McChesney and Nichols talk about in regards to the United States is already a phenomenon in our region. They wrote:

In media today, even among journalists who entered the field for the noblest of reasons, there is an internalised bias to simply shy away from controversial journalism that might enmesh a media firm in a battle with powerful corporations or government agencies. (McChesney \& Nichols, p. 59)

The outcome of this kind of media bias, sadly so I might add, is that corporations (or simply those who advertise or fund media) as well as governments are being protected from public scrutiny and the critical watchdog role, which is a fundamental function of media. We are seeing a major shift of the balance of media power from traditional journalism to the public relations industry. This is the case in Australia and New Zealand, as well as in the bigger island states of our region; and the media training institutions have responded accordingly with training programmes to accommodate this shift.

At worst, public relations simply is the art of putting a spin on news coverage making it sympathetic to its clients; at best, public relations agents are professionals who use their media knowledge to communicate effectively for their clients or their employers.

In the US, it is estimated there are 20,000 more PR agents than there are journalists. And in our region, there is an incredible growth in the consultants and PR industry; journalists and media trained practitioners are at the front of the line of those preferred for hiring in that industry.

It is interesting to note the government of Tonga hired a PR agent from Fiji to advise them on their media policies and what they needed to do during the banning of our newspaper, Taimi 'o Tonga. They also consulted media PR firms in Australia and New Zealand. Press releases emerging from the Prime Minister's Office - and supported by their newspaper, radio, and television were not only outrageous in content, but also vicious in its attempt to destroy any voice of dissent. 


\section{THE INDIGENOUS PUBLIC SPHERE}

Their actions come as no surprise. Over the last two decades, public relations and advertising industries have developed as powerful instruments of government propaganda in the islands. In fact, governments have themselves become one of the most significant advertisers in any island state. Now even non-government media often walk carefully in their relationship with governments for fear of loss of advertising revenue from them.

The reality is that we live in an AM era - 'After Money' - yet we must work to reform media so that the information needs of our societies can be met, irrespective of money. There was a BM era sometime long ago - 'Before Money'.

\section{Serving the elitist few rather than the masses of common people}

Publishing or broadcasting news stories is not just a case of providing information to a society about themselves but doing it in interesting and appropriate ways with immediate relevance to the lives of the people. I think it was Ben Bradlee, the famed former editor of The Washington Post, who said: 'News is the first rough draft of history'.

If writing news stories is writing a rough draft of history, then the question we need to ask in our region is 'whose history are we writing?' If we are to look at the news stories being written or broadcast in today's national and regional media, it is amazing how many of them reflect only a small section of society. Most are elitist in nature. In other words, the stories told are those of the elite in our societies, almost as though the common people, or the majority of our population, do not have stories to tell.

In his epilogue to the book Remembrance of Pacific Pasts (Borofsky, p. 458), Tongan sociology professor 'Epeli Hau'ofa wrote:

Human events occur as interaction between people in time and space. First we look at people. In our reconstructions of Pacific histories of recent past, for example, we must clear the stage and bring in new characters. We bring to the centre stage, as main players, our own peoples and institutions.

Most written histories of our region mostly feature the lives and activities of kings, queens, chiefs, and nobles in their interaction with explorers, traders, missionaries, and colonisers. The modern media have followed this narrow 
treatise of history by writing or broadcasting news catering to the elite.

Any reform of the media must include the need for the people's stories to be told, that the masses of common people must be given the right to determine those matters which are most important in their lives. They need to be the determiners of their own future, rather than kings, queens, and chiefs whose decision making and practices have often been in direct conflict with the interest of the people.

Our people have long experienced the oppressive exploitation by our royalties and chiefs. The oppression that our people suffered, in all its different forms - slavery, class and gender discrimination, gross violation of human rights, and so on - was brought upon us, not by foreigners but by our own kings and chiefs.

Oppression was prevalent in our region before colonisers came. The colonisers only added their own brand of oppression, but the peoples of the $\mathrm{Pa}$ cific were generally under oppression from their own kings, chiefs and aristocrats. Even after the colonisers were dispelled, a new brand of chiefly 'colonisation' took over. Our predators were our own rulers. Unfortunately the situation has not changed much to this day.

We need to reconstruct our history, and hopefully our region's media will play the key role in this, for the stories of our past centre-staged the elite. They were the main characters; the rest of the people were either spectators (as opposed to participators) in much of the historical narrative we have, or simply the 'extras' used to give support, and give a kind of delusive meaning to the activities of the main players.

But the stories of our people need to be told in languages and images they can relate to. This is why the role of the vernacular media in the indigenous public sphere is so important; they should be the mainstream media of any society, media in the language of the people, not necessarily in the language of commercialism and business interests, but of the people.

Why is it that there are mostly American programmes being shown on island television? Those programmes reflect American culture and American society. That is fine for Americans, but where are our programmes and the shows that reflect our culture and our society?

The major regional radio broadcasts come from Australia and New Zealand. We are thankful to Radio Australia and Radio New Zealand for those broadcasts, which inform us of what is happening in their countries, and also 
help us learn English, for many of those broadcasts are in English.

What societies and what cultures are being reflected in those broadcasts? But they are more helpful than harmful. For they cover some regional news that are being broadcast back to the island states in English.

Again, I want to emphasise that without vernacular media, the information we are trying to pass on to our people is so much wrapped in language and images that are foreign and inappropriate, and cater to a minority who speak English and who may understand foreign imagery. Even those who speak English do not necessarily think in that language.

Worst of all, depending on English (or French) media as the mainstream media in the region not only ignores the significance of vernacular media, but is in itself a form of re-colonisation for nothing is more effective in passing on of values than language.

I believe that if media are directed first at the people in grassroots as a requirement, then we will have fulfilled our duty to society, and even make a good living doing so. An understanding of the peoples and cultures of the Pacific is of paramount importance if one is to be an effective communicator. But the cultural traditions of our peoples cannot be used by elitist rulers to hide behind, as a means of escaping the necessary scrutiny they so desperately deserve.

To use the guise of cultural sensitivity as a cover to protect oneself from criticism is an insult to that culture, for the implication is that culture does not condone transparency, honesty, order, and proper management of affairs.

Corrupt and dishonest politicians and bureaucrats have often reacted to media scrutiny by throwing up a pretentious cover of cultural taboos and cultural insensitivities as excuses to avoid being scrutinised.

There needs to be a redefinition of our people. We are no longer just peoples that are confined geographically to groups of islands in the vast $\mathrm{Pa}$ cific Ocean but our peoples are spread around the world in diaspora. Those who are in diaspora are just as much Pacific, and they play a huge role in the democratisation of the Pacific, the effecting of cultural and social change, and most significantly economic contribution through remittances, tourism, and business investments to our island states.

Countries like Samoa, Tonga, Tuvalu, Cook Islands and Niue have more of their people living outside than inside their countries. They are migrants who have settled in New Zealand, Australia and the United States. And with 
them, they have taken their language, culture, and ways of life, and have adapted to their host nations quite effectively.

If media are to reflect accurately all that is happening among our peoples in the region, the communities of migrants in Australasia and the United States must be included for they are just as Pasifika as those that live in the islands.

\section{Conclusion}

We must redefine our roles as media in this AM 'After Money' era. Our media systems need reform so we can effectively serve our societies' needs, instead of confining our services to enriching the few and catering merely to the dictates of our elitist rulers. Journalism education and training must take into account the various trends affecting our industry.

\section{Notes}

${ }^{1}$ Fusitu'a, 'E. (2004, August 30). Witness at the Supreme Court in Nuku'alofa.

${ }^{2}$ New International Version, 2 Samuel 11.1-27, 12.1-10. Grand Rapids: Zondervan.

\section{References}

Borofsky, R. (Ed.). (2000). Remembrance of Pacific pasts. Honolulu: University of Hawaii Press.

McChesney, R. W. \& J. Nichols. (2002). Our media, not theirs. New York: Seven Stories Press.

Kalafi Moala is publisher of the Auckland-based Lali Media Group, publishing newspapers such as Taimi 'o Tonga. This commentary was the keynote address given at the Journalism Education Association (JEA) conference in Suva, Fiji Islands, 6-9 December 2004.

kalafim@yahoo.com.au 